\title{
Representasi Sikap Sabar dalam Novel Cinta Laki-Laki Biasa Karya Asma Nadia
}

\author{
Erlina Zahar, Sujoko \\ Dosen Fakultas Keguruan dan Ilmu Pendidikan Universitas Batanghari \\ Jl. Slamet Ryadi, Broni-Jambi \\ Correspondence email: erlina_zahar@yahoo.co.id
}

\begin{abstract}
This study aims to describe the representation of patience value in the novel Cinta Laki-laki Biasa by Asma Nadia. This type of research is literary research, which is descriptive qualitative. The research data was taken from the novel Cinta Laki-laki Biasa by Asma Nadia, namely words, sentences, and paragraphs that express quotations representing patient attitudes. The data source of this research is the novel Cinta Laki-laki Biasa by Asma Nadia. The data collection technique in this research is to use the documentation carried out to analyze the contents of a novel, especially the representation of patience value in the novel Cinta Laki-laki Biasa by Asma Nadia. The results showed that the representation of patience in accepting various trials in the novel Cinta Laki-laki Biasa by Asma Nadia contained 26 quotes.
\end{abstract}

Keywords: Representation; Patience; Ordinary Male Love

\section{PENDAHULUAN}

Karya sastra lahir dari goresan pena sastrawan. Karya sastra diciptakan berdasarkan fenomena yang terjadi di tengah manusia dan kehidupan. Fenomena ini dikreasikan oleh sastrawan ke dalam imajinasinya, sehingga melahirkan karya sastra. Karya sastra yang lahir mengemukakan fenomena hidup dan kehidupan manusia, yang akan bermanfaat bagi penikmat sastra.

Karya sastra yang terlahir dari kreasi seni sastrawan memiliki berbagai manfaat bagi penikmat sastra. Sebagai karya yang dikemas dengan penuh artistik, baik dari sisi pilihan katanya maupun dari substansi isi karya sastra itu akan menjadi penghibur bagi manusia. Salah satu penghibur manusia adalah kisah-kisah yang ditampilkan dalam karya sastra.

Selain bermanfaat sebagai penghibur, substansi karya sastra juga bermanfaat sebagai pedoman hidup dalam menjalankan kehidupan manusia. Fenomena hidup dan kehidupan manusia dengan segala kurenahnya dijadikan inspirasi bagi sastrawan untuk menciptakan karya sastra. Karya sastra yang berisikan tentang nilainilai humanistik dan nilai-nilai konseptual kemanusiaan yang dibingkai dengan artistik oleh seorang sastrawan akan bernilai guna sebagai suri tauladan dalam menjalankan kehidupan manusia. Selain itu, membaca karya sastra dapat merubah pola pikir dan menambah wawasan pengetahuan serta sebagai sumber inspirasi bagi penikmat sastra. Dengan demikian, membaca sastra dapat menjadikan kehidupan manusia menjadi lebih baik.

Fenomena kehidupan manusia dengan segala bentuk aktivitasnya dapat dijadikan sumber inspirasi oleh sastrawan dalam menciptakan karya sastra. Berbagai jenis karya sastra dengan mengungkapkan fenomena kehidupan manusia akan lahir dari goresan pena sastrawan. Seperti yang kita ketahui jenis karya sastra sebagai wujud nyata kreativitas sastrawan berupa drama, puisi, dan prosa. Prosa sebagai salah satu jenis dari karya sastra merupakan karya yang banyak disukai oleh penikmat karya sastra. Salah satu jenis dari prosa adalah novel.

Novel adalah suatu karya sastra yang menceritakan tentang kehidupan yang dijalani oleh manusia. Novel merupakan jenis dari karya sastra yang banyak disukai oleh masyarakat. Novel dapat dibaca oleh semua kalangan baik muda, dewasa, maupun tua. Novel dapat dijadikan teladan serta tuntunan hidup bagi pembaca. Membaca novel dapat memberikan inspirasi bagi pembaca. Novel yang berisikan tentang sikap nilai manusia akan menjadi bagian dari pengetahuan kemanusiaan yang dapat dijadikan sumber bacaan. Misalnya saja sikap sabar sebagai bagian dari sikap hidup yang harus dimiliki dalam kehidupan manusia. Novel-novel yang memuat sikap-sikap luhur yang harus dimiliki manusia sebagai substansi cerita yang dikisahkan dalam novel dapat dijadikan kaca bagi penikmat sastra.

Pada era globalisasi berbagai sikap dan nilai luhur manusia mulai tergerus. Diantaranya wujud rasa sabar yang terkadang sering hilang dalam kendali kehidupan manusia. Dewasa ini sering kali kita dengar dan kita saksikan betapa mudahnya emosi manusia tersulut hingga melakukan hal-hal yang tidak manusiawi akibat tidak terpeliharanya sikap sabar dengan baik. Representasi rasa sabar seringkali lenyap yang diikuti dengan emosional yang tak terkendali. Seperti berita yang pernah kita dengar tentang hilangnya kesabaran seorang suami dan bapak dari seorang anak yang bernama Iwan yang menganiaya istri dan anaknya berulang kali karena istri dan anaknya selalu bermain handphone setiap kali dia pulang dari kantor. Amarah Iwan memuncak dan rasa sabar hilang. Diluar dugaan Iwan mengikat tangan dan kaki anaknya yang masih kecil di kursi sofa. Setelah itu, tanpa menggunakan 
logika Iwan menyetrum istrinya dengan sengatan aliran listrik. Akibatnya, korban mengalami luka di sekujur tubuh (https://daerah.sindonews.com.topic.17/09/2018). Seseorang melakukan segala cara untuk bisa mencapai tujuan yang diinginkan tanpa memikirkan dampaknya bagi orang lain. Fenomena di atas menggambarkan telah bergesernya nilai-nilai kemanusiaan yang seharusnya dengan kesabaran keadaan tersebut dapat dikomunikasikan dengan lebih manusiawi. Bila substansi yang di kedepankan dalam novel berisikan tentang kesabaran manusia, maka bacaan ini dapat bernilai guna bagi sikap dan perilaku manusia dalam kehidupan. Dengan demikian, novel yang bersubstansi sikap nilai manusia diharapkan dapat menurunkan tingkat rendahnya moralitas manusia.

Salah satu novel yang mengedepankan representasi rasa bersabar adalah novel Cinta Laki-laki Biasa Karya Asma Nadia. Novel Cinta Laki-laki Biasa Karya Asma Nadia diterbitkan oleh Asma Nadia Publishing House. Novel ini diterbitkan pada bulan November 2016. Novel ini berjumlah 264 halaman. Novel Cinta Laki-laki Biasa Karya Asma Nadia memiliki sampul yang menarik yakni berwarna hitam bercampur biru, kuning dan putih yang menarik pembaca untuk membacanya. Novel ini laku keras dalam waktu seminggu terjual 1000 eksemplar. (https://www.Referensibukubagus.Wordpress.com.17/04 12018). Novel ini sepintas terlihat menceritakan drama romantis tentang kesederhanaan akan cinta yang menawarkan unsur kedamaian yang disampaikan Islam melalui cinta seorang laki-laki biasa. Novel ini dapat menumbuhkan kesadaran manusia akan kesabaran dalam menghadapi kenyataan hidup teguhnya karakter dan tingginya kesadaran iman tergambar di dalam novel ini. Sehingga novel ini layak untuk dibaca oleh penikmat sastra.

Berdasarkan paparan yang telah peneliti ulas di atas, maka peneliti tertarik untuk menganalisis novel Cinta Laki-laki Biasa karya Asma Nadia dari representasi sikap sabar. Alasan peneliti untuk meneliti ini adalah sebagai berikut:

1. Karya sastra yang berisi hidup dan kehidupan manusia bermanfaat sebagai sarana hiburan dan sebagai acuan kehidupan bagi manusia.

2. Novel merupakan jenis karya sastra yang banyak diminati penikmat sastra.

3. Novel Cinta Laki-laki Biasa karya Asma Nadia berisikan tentang kehidupan manusia yang mencakup ketulusan cinta, kesederhanaan, kedamaian, kesadaran iman, karakter serta sikap sabar yang dapat dijadikan pedoman hidup.

4. Asma Nadia seorang novelis yang karyanya banyak mendapat penghargaan serta predikat novel terbaik di antaranya novel Cinta Laki-laki Biasa.

Adapun tujuan penelitian ini adalah untuk mendeskripsikan representasi sikap sabar dalam novel Cinta Laki-laki Biasa karya Asma Nadia.

\section{METODE PENELITIAN}

Penelitian yang peneliti laksanakan ini termasuk jenis penelitian deskriptif kualitatif. "Deskriptif merupakan prosedur pemecahan masalah yang diselidiki dengan mendeskripsikan atau melukiskan keadaan subjek atau objek penelitian (novel) pada saat sekarang berdasarkan fakta-fakta yang tampak atau sebagaimana adanya" (Siswantoro, 2010:56). Sedangkan, "Penelitian kualitatif dilakukan dengan tidak mengutamakan pada angka-angka, tetapi mengutamakan kedalam penghayatan terhadap interaksi antara konsep yang sedang dikaji secara empiris" (Semi, 2012:23). Penelitian ini menggambarkan tentang objek yang akan diteliti atau data yang dianalisis dengan menggunakan kata- kata yang sesuai dengan kebenaran yang ada. Dengan jenis penelitian deskriptif peneliti dapat menggambarkan aspek sabar dalam Novel Cinta Lakilaki Biasa Karya Asma Nadia.

Dalam penelitian ini, dari novel Cinta Laki-laki Biasa karya Asma Nadia, data yang diambil untuk analisis dari setiap kata-kata, kalimat dan paragraf yang menggungkapkan kutipan representasi sikap sabar. Sedangkan, sumber data merupakan data yang dihasilkan oleh peneliti adalah novel. Novel merupakan salah satu data yang didapatkan oleh peneliti. Novel Cinta Laki-laki Biasa Karya Asma Nadia yang diterbitkan oleh Publishing House pada Bulan November 2016. Novel ini berjumlah 264 halaman. Novel ini memiliki berat 300 gram dengan ukuran $13,5 \times 20,5 \mathrm{~cm}$. Sampul novel ini berwarna hitam bercampur biru, kuning dan putih, sehingga menartik untuk dibaca oleh penikmat sastra. Sumber peneliti peroleh dari tokoh buku.

\section{HASIL PENELITIAN DAN PEMBAHASAN Hasil}

Berdasarkan hasil penelitian yang telah dilakukan, peneliti menemukan kutipan-kutipan berbentuk kata, kalimat, paragraf yang berkaitan dengan representasi sikap sabar dalam novel Cinta Laki-laki Biasa karya Asma nadia. Representasi sikap sabar terlihat dari sabarnya tokoh-tokoh cerita menerima cobaan yang tergambar dari kutipan-kutipan novel Cinta Laki-laki Biasa karya Asma Nadia.

Representasi kesabaran Rafli seperti tak bertepi untuk mengembalikan rasa cinta Nania sebagai istrinya kembali direbut untuk dirinya dan anak-anak. Kutipankutipan yang berkaitan dengan representasi sikap sabar yang terdapat dalam novel Cinta Laki-laki Biasa karya Asma Nadia akan dijelaskan pada bagian di bawah ini. Judul novel Cinta Laki-laki Biasa peneliti menyingkatnya menjadi $C L L B$. Kutipan dalam novel ini terdapat 26 kutipan, yaitu:

(4.1) "Nania Cuma mau Rafli," sahutnya lirih dengan air mata mengembang sembari berharap. Hari itu ia tahu, keluarganya bukan 
sekedar tidak suka, melainkan sangat tidak menyukai Rafli” (CLLB: 5).

(4.2) "Lelaki biasa itu tak pernah lelah merawat Nania selama belasan tahun kemudian. Memandikan dan menyuapi Nania, lalu mengantar anak-anak ke sekolah satu per satu" (CLLB : 15).

(4.3) "Hei! Menepilah, bujang lapuk kami ingin membeli tahumu." Mendengar panggilan itu mau marah, tapi bagaimana dagangannya tak akan laku. Bandrun pun menepi dengan diselengi senyum sebagaimana keahliannya menjadi pedagang" (CLLB: 25-26).

(4.4) "Pandangan Anak Tunggal Umi Khabubah itu menajam. Ada nyala api di matanya. Tapi segera saja ia padamkan, sekuat jiwa meredam nafsu. Ia teringat kembali amanah biyung sepanjang hidup, bapak selalu bersikap santun walau terhadap orang yang membenci sekalipun" (CLLB: 26-27).

(4.5) "Mas Roni, ini makan malamnya, Mas. Tadi aku beli di dekat kantor." Bungkusan kertas berisi sate dan lontong kuletakkan di meja kecil. Ia hanya menggumam malas, tangannya lebih rajin dibanding mulutnya" (CLLB: 51).

(4.6) "Untuk apa dipertahankan jika tidak cocok? Apalagi kalian hanya dijodohkan, bukan kemauan sendiri." Telinga ini sudah luar biasa kenyang dengan beragam saran yang nyaris seluruhnya bermuara pada perceraian. Aku sudah memantapkan hati mengurus suami” (CLLB: 53).

(4.7) "Ini kaki gunung dan sisa jalan masih jauh. Ojek sedia buat mendaki tapi memilih jalan kaki. Olahraga dan menikmati alam menjadi alasan, tapi alibi sesungguhnya hemat uang, lumayan buatmu jajan." (CLLB: 65-66).

(4.8) "Ada enam anak muda yang mengaku anak bapak. Mereka datang tadi pagi. Bagaimana ini? Kok, aku sendiri tidak pernah tahu. Barangkali kamu pernah dengar bapak bicara tentang istri-istri yang lain?" kata ibu dengan suara tetap datar. Tak tersirat emosi" (CLLB:72).

(4.9) "Tapi Mas Win ndak pernah mau memanggil Riani dengan nduk, Mbok. Padahal rasanya spesial setiap kali dipanggil seperti itu. Rasanya juga nyaman dan selalu dilindungi." Mata riani yang sebening dan seteduh telaga kini beriak" (CLLB: 85).

(4.10) "Rumah bagi Win tak lebih sebagai halte. Namun dengan sabar Riani mengurus dua putri mereka seorang diri. Dari pagi hingga gelap hari. Win bahkan tak pernah sekedar menelpon, memastikan apakah anak-anak sehat. Apakah ibu dari anak-anaknya cukup istirahat?" (CLLB: 87).

(4.11) "Riani tak menyalahkan Bastian karena ia yang memilih takdirnya sendiri. Ia yang menerima win tak lama setelah Bastian pergi. Riani mengerti setiap pilihan melahirkan konsekuensi. Ia harus menerima paket lengkap Win termasuk ketika Win mengabaikannya" (CLLB: 89).

(4.12) "Riani membuatkan secangkir teh. Tapi sering teh itu dingin telantar hingga barisan semut hitam menemukan cawan tempat pesta pora dan Win, ia terus sibuk dengan gadget yang berjajar di meja batang racun yang terselip di bibirnya" (CLLB: 91).

(4.13) "Riani menangis untuk sebuah cinta yang masih serupa warnanya. Bahkan Riani rela kehilangan cinta meninggalkan Bastian begitu cepat. Dahulu, ia menerima Win karena sebuah kebutuhan" (CLLB: 94).

(4.14) "Dada ini rasanya sesak namun ku tahan melihat laki-laki yang sangat kucintai terbaring tak berdaya. Bapak terlihat lebih tua sepuluh tahun dari usianya. Janggut dan cambang menghiasi tulang pipinya yang menonjol" (CLLB: 103).

(4.15) "Ternyata kau menatapku karena cinta seorang kakak pada adiknya yang telah tiada. Sekuat tenaga kutahan dengan penuh sabar agar bulir-bulir kristal tak luruh, jatuh di depan kalian" (CLLB: 111).

(4.16) "Lelaki yang saya sukai itu telah melukai dengan keputusannya untuk menghilang, lalu meminta saya menunggu di sini, tapi tak datang menemui. Sungguh, saya akui diri ini begitu sabar karena mau dilukai cinta yang belum tentu jodoh" (CLLB: 145).

(4.17) "Ayah meraih koran itu dan membacanya. Faisal tentu saya berharap setelah membacanya, Ayah akan berubah keputusan. Tapi Faisal harus menelan ludah getirnya ketika Ayah mencibir sambil meletakkan 
koran. Jadi itu yang menurutmu hebat? Jangankan denting kecapi bugis, bahkan gantungan kunci pun akan digilai orang-orang luar negeri" (CLLB: 147).

(4.18) "Saya paham maksud ibu. Ia meminta saya sepertinya, menyerahkan semua keputusan pada Ayah. Suka atau tidak. Padahal dalam hati, saya ingin sekali berlari dari rumah, atau paling tidak melawan Ayah dengan suara tinggi, tapi hidup hanya memberi satu pilihan. Bersabarlah!"' (CLLB: 153).

(4.19) "Ibu yang pertama memecah sunyi. Saya belum bisa bersikap apa pun, meski hanya sekedar mengangguk. Suara langkah Ayah yang meninggalkan ruang tamu, saya terjemahkan dengan kalimat memvonis:siapa pun dia, kamu harus menerimanya. Sidang ditutup. Tak ada banding!" (CLLB: 155).

(4.20) "Selamat tinggal, Faisal! Batin saya sambil melangkah ke ruang tamu untuk menemui lelaki pengusaha pilihan Ayah. Saya tak bisa membiarkan diri dalam kebodohan panjang dengan mempertahankan cinta yang bukan jodoh, meski waktu telah membuat saya tangguh untuk terluka" (CLLB: 156-157).

(4.21) "Aku bakal kangen terus sama kamu, sama ibu! Nessa memecah hening. Bening air matanya leleh menderas. Matanya menatapku penuh. Mata yang penuh cinta" (CLLB: 162).

(4.22) "Merawatnya dengan telaten, menunggui sampai dia sembuh dan mulai lagi menjalani kehidupan seperti semula. Namun yang terjadi sungguh di luar harapan. Berbulan-bulan Mas Dibku sayang tetap berbaring di tempat tidur. Kondisinya kian bertambah buruk" (CLLB: 175).

(4.23) "Dalam perjalanan ke kantor, banyak hal berputar dan menyesaki pikiranku. Tentang bulan madu yang hanya sesaat. Tentang sakitnya Mas Didku sayang, sikap Mama, serta sikap orang-orang yang seolah ingin mengambil keuntungan dari peristiwa yang $\mathrm{ku}$ alami" (CLLB: 179).

(4.24) "Bunda, hati aku seperti berlubang, sakit sekali. Bunda.... bangun, Bunda!. Hingga akhirnya, setelah merasakan kehampaan yang panjang...."Bunda, kalau Bunda kesakitan, Bunda pergi saya ya, Bunda? Yunnan nggak apa-apa kok, nggak ada Bunda. Tidak ada suara lagi dalam waktu lama, hanya rintihan halus" (CLLB: 195).

(4.25) "Tolonglah $\mathrm{Bu}$, saya sudah tidak tahu lagi harus berbuat apa. Saya selalu berusaha memberikan yang terbaik, tapi ia seperti tidak bisa melupakan ayahnya. Bahkan saya sedang pusing memikirkan kakaknya Citra, Dita" bukan upaya membela diri." (CLLB: 202).

(4.26) "Perempuan di hadapannya menunduk berangsur membuka mulut dan berbicara dengan suaranya bergetar, "Setiap hari. Hampir setiap hari ia selalu berteriak, Ayah....Ayah.....Ayah....!" (CLLB: 202).

\section{Pembahasan}

Pembahasan pada penelitian ini membahas tentang analisis representasi sikap sabar yang berkaitan dengan aspek bersabar menerima cobaan dalamnovel Cinta Laki-laki Biasa Karya Asma Nadia. Peneliti akan menjelaskan pembahasan tersebut pada bagian di bawah ini.

(4.1) "Nania Cuma mau Rafli," sahutnya lirih dengan air mata mengembang sembari berharap. Hari itu ia tahu, keluarganya bukan sekedar tidak suka, melainkan sangat tidak menyukai Rafli” (CLLB: 5).

Kutipan (4.1) di atas menjelaskan bahwa keluarga Nania yang berasal dari keluarga yang berada tidak menyetujui dan menolak lamaran Rafli yang merupakan laki-laki biasa. Semua keluarga Nania tidak ada yang menyukai Rafli dan berharap Nania menemukan jodoh yang sepadan atau sama dengan keluarga nya. Nania selalu disudutkan oleh keluarganya dan Nania tetap bersaba, memohon dengan mengatakan dia cuma mau Rafli. Nania tidak bisa berbuat apa-apa sambil meneteskan air mata. Representasi sikap sabar Nania ini diperlihatkannya setiap perbincangan keluarganya terhadap penolakan perimaan Rafli. Namun Nania membalasnya dengan sabar. Nania tidak putus asa di dalam menghadapi kenyataan ini dengan harapan keluarganya bisa luluh.

(4.2) "Lelaki biasa itu tak pernah lelah merawat Nania selama belasan tahun kemudian. Memandikan dan menyuapi Nania, lalu mengantar anak-anak ke sekolah satu per satu" $(C L L B: 15)$.

Kutipan (4.2) di atas menjelaskan bahwa baru beberapa tahun Nania berumah tangga dengan Rafli Nania mengalami kecelakan dan membuat dia lumpuh 
sehingga tidak bisa berjalan dengan normal menggunakan bantuan kursi roda. Suami Nania yaitu Rafli selalu sabar dalam merawat Nania dan menjaga Nania. Setiap hari suaminya selalu mengerjakan pekerjaan sendiri seperti mengantar anak sekolah, memandikan, menyuapi, mengajak Nania jalan-jalan dengan penuh kesabaran. Representasi sikap sabar Rafli yang tidak mengeluh dengan keadaan Nania sekarang yang selalu sabar dan tabah menjalani kehidupannya seperti sekarang.

(4.3) "Hei! Menepilah, bujang lapuk kami ingin membeli tahumu." Mendengar panggilan itu mau marah, tapi bagaimana dagangannya tak akan laku. Bandrun pun menepi dengan diselengi senyum sebagaimana keahliannya menjadi pedagang" (CLLB: 25-26).

Kutipan (4.3) di atas menjelaskan bahwa ada seorang laki-laki sederhana yang tinggal sendiri ketika ibu dan ayahnya meninggal dunia. Dia berjualan tahu keliling desa dan ketika berjualan tiba-tiba ada beberapa laki-laki yang datang menghampiri ingin membeli tahun namun laki-laki tersebut malah mengejek laki-laki sederhana ini. Dia mengatakan bujang lapuk, sudah tua belum beristri dan banyak mengeluarkan kata-kata yang tidak seharusnya diucapkan. Namun, Badrun laki-laki sederhana ini memperlihatkan sikap sabarnya dan tidak marah dalam menanggapi perkatan laki-laki itu. Dia menahan emosi dengan sabar karena dia teringat katakata ayahnya jika ada orang lain yang membencimu jangan balik membencinya. Representasi sikap Badrun ini menunjukkan bahwa ia tabah, sabar diuji ketika mendapat cobaan.

(4.4) "Pandangan Anak Tunggal Umi Khabubah itu menajam. Ada nyala api di matanya. Tapi segera saja ia padamkan, sekuat jiwa meredam nafsu. Ia teringat kembali amanah biyung sepanjang hidup, bapak selalu bersikap santun walau terhadap orang yang membenci sekalipun" (CLLB: 26-27).

Kutipan (4.4) di atas menjelaskan bahwa badrun selalu mengingat kata-kata Bapaknya bahwa selalu bersikap santun walalupun terhadap orang yang membenci sekalipun. Badrun terlihat menahan amarahnya dengan sabar, air mata ditahannya dengan sekuat jiwa meredam nafsu karena dihina oleh orang lain. Representasi sikap sabar Badrun dalam menerima cobaan dijadikannya sebagai harapan agar ia dapat berhasil di kemudian hari.

(4.5) "Mas Roni, ini makan malamnya, mas. Tadi aku beli di dekat kantor." Bungkusan kertas berisi sate dan lontong kuletakkan di meja kecil. Ia hanya menggumam malas, tangannya lebih rajin dibanding mulutnya" (CLLB: 51).

Kutipan (4.5) di atas menjelaskan bahwa ada seorang istri yang selalu melayani suaminya dengan penuh perhatian dan selalu melakukan kewajibannya sebagai istri. Namun, suaminya selalu dingin padanya. Ketika dia memberikan sebungkus sate dan lontong pada suaminya dan diletakkan di atas meja. Suaminya tidak menjawab ataupun mengeluarkan kata-kata terima kasih dan asyik dengan handponenya. Istrinya sabar menghadapi suaminya yang selalu dingin padanya. Representasi sikap sabar istrinya ini diperlihatkan dalam menerima sikap tak adil dari suaminya dan berharap suatu saat derajatnya menjadi tinggi.

(4.6) "Untuk apa dipertahankan jika tidak cocok? Apalagi kalian hanya dijodohkan, bukan kemauan sendiri." Telinga ini sudah luar biasa kenyang dengan beragam saran yang nyaris seluruhnya bermuara pada perceraian. Aku sudah memantapkan hati mengururs suami" (CLLB: 53).

Kutiupan (4.6) di atas menjelaskan bahwa seorang istri yang mengharapkan suaminya bisa sembuh kembali seperti biasa karena suaminya mengalami kecelakan dan membuat suaminya terbaring di rumah berbulan-bulan. Istrinya tetap bersikap sabar merawat suaminya dan tidak pernah putus asa untuk kesembuhan suaminya. Banyak teman-teman serta keluarganya mengatakan untuk menikah lagi dengan laki-laki lain tapi istrinya tetap sabar dan tidak pernah putus asa dan selalu sabar menanggapi kata-kata orang disekelilingnya dengan prinsip sudah memantapkan hati untuk mengurus suaminya.

(4.7) "Ini kaki gunung dan sisa jalan masih jauh. Ojek sedia buat mendaki tapi memilih jalan kaki. Olahraga dan menikmati alam menjadi alasan, tapi alibi sesungguhnya hemat uang, lumayan buatmu jajan." (CLLB: 65-66).

Kutipan (4.7) di atas menjelaskan bahwa seorang ayah rela dengan sabar jalan kaki melewati gunung dengan perjalanan yang masih sangat jauh. Semuanya demi bertemu anaknya dan untuk mengirit biaya jika menggunakan ojek karena uangnya bisa untuk jajan anaknya di rumah. Ayahnya tidak pernah putus asa dan lelah yang dirasakannya hilang ketika bertemu keluarganya.

(4.8) "Ada enam anak muda yang mengaku anak bapak. Mereka datang tadi pagi. Bagaimana ini? Kok, aku sendiri tidak pernah tahu. Barangkali kamu pernah dengar bapak 
bicara tentang istri-istri yang lain?" kata ibu dengan suara tetap datar. Tak tersirat emosi" (CLLB:72).

Kutipan (4.8) di atas menjelaskan bahwa ketika bapak angkatnya meninggal dunia datanglah enam anak pemuda yang mengaku anak bapak. Yang membuat ibunya dan anak angkatnya terkejut. Mereka tidak mengetahui enam anak tersebut karena bapak tidak pernah cerita. Ibu berpikiran bahwa bapak menikah lagi diam-diam tanpa sepengetahuan ibu. Namun ibu tidak marah pada anak tersebut. Ibu dengan sabar dan tenang mengatakan pada anak angkatnya barangkali kamu pernah dengar bapak berbicara tentang istri-istri yang lain. Bersabar tanpa emosi, tabah serta selalu berpikir husnozon dengan kejadian yang di alami.

(4.9) "Tapi Mas Win ndak pernah mau memanggil Riani dengan nduk, Mbok. Padahal rasanya spesial setiap kali dipanggil seperti itu. Rasanya juga nyaman dan selalu dilindungi." Mata riani yang sebening dan seteduh telaga kini beriak" (CLLB: 85).

Kutipan (4.9) di atas menjelaskan bahwa Riani mengatakan pada mboknya bahwa suaminya tidak pernah memanggil sebutan yang sering mbok panggil untuk Riani. Riani padahal berharap sekali mas Win suaminya bisa memanggilnya dengan sebutan Nduk. Kata Nduk membuat Riani merasa menjadi seorang yang spesial juga rasa nyaman dan selalu dilindungi. Riani hanya bisa sabar dan berharap suatu saat suaminya bisa memanggilnya dengan sebutan Nduk. Riani bersabar menunggu dan berharap suatu saat suaminya bisa memanggilnya dengan sebutan Nduk.

(4.10) "Rumah bagi Win tak lebih sebagai halte. Namun dengan sabar Riani mengurus dua putri mereka seorang diri. Dari pagi hingga gelap hari. Win bahkan tak pernah sekedar menelpon, memastikan apakah anak-anak sehat. Apakah ibu dari anak-anaknya cukup istirahat?" (CLLB: 87).

Kutipan (4.10) di atas menjalaskan bahwa suami Riani tidak pernah lama berada di rumah. Dia menganggap rumah tidak lebih sebagai halte. Dia sibuk dengan urusan kerja dan menghabiskan waktu di luar rumah. Riani bersikap sabar dan tetap menjalankan kewajiban mengurus dua putri mereka dari pagi hingga gelap hari seorang diri. Riani bersabar menerima perlakuan suaminya dengan harapan akan terjadi perubahan.

(4.11) "Riani tak menyalahkan Bastian karena ia yang memilih takdirnya sendiri. Ia yang menerima win tak lama setelah Bastian pergi.
Riani mengerti setiap pilihan melahirkan konsekuensi. Ia harus menerima paket lengkap Win termasuk ketika Win mengabaikannya" (CLLB: 89).

Kutipan (4.11) di atas menjelaskan bahwa Riani bertemu dengan mantan kekasihnya dulu yang sangat menyayanginya hingga kini. Riani tidak dapat bersatu dengan kekasihnya karena takdir yang berkata lain. Riani tidak pernah menyesali apa yang telah terjadi padanya sekarang karena segala sesuatu pasti akan akan konsekuensinya dan dia menerima itu semua dengan penuh kesabaran.

(4.12) "Riani membuatkan secangkir teh. Tapi sering teh itu dingin telantar hingga barisan semut hitam menemukan cawan tempat pesta pora dan Win, ia terus sibuk dengan gadget yang berjajar di meja batang racun yang terselip di bibirnya" (CLLB: 91).

Kutipan (4.12) di atas menjelaskan bahwa Riani selalu melayani suaminya dengan baik namun kebaikannya tidak pernah dihargai oleh suaminya. Riani membuatkan secangkir teh namun suaminya asyik dengan handponenya sendiri dan tidak memperdulikan istrinya. Bahkan terkadang teh yang Riani buat tidak diminum oleh suaminya sampai barisan hitam semut berjejeran datang ke tempat minumannya. Namun Riani tetap bersikap sabar dan selalu melayani suaminya dengan baik.

(4.13) "Riani menangis untuk sebuah cinta yang masih serupa warnanya. Bahkan Riani rela kehilangan cinta meninggalkan Bastian begitu cepat. Dahulu, ia menerima Win karena sebuah kebutuhan" (CLLB: 94).

Kutipan (4.13) di atas menjelaskan bahwa Riani merasakan bahwa cinta yang dulu tidak pernah berubah antara dirinya dan mantan kekasih masih sama seperti dulu. Riani menyesali karena telah meninggalkan kekasihnya begitu cepat dan memilih suaminya yang sekarang. Namun Riani hanya bisa sabar dan menangis menerima kenyataan hidupnya seperti ini. Bersabar menerima cobaan yang datang silih berganti.

(4.14) "Dada ini rasanya sesak namun ku tahan melihat laki-laki yang sangat kucintai terbaring tak berdaya. Bapak terlihat lebih tua sepuluh tahun dari usianya. Janggut dan cambang menghiasi tulang pipinya yang menonjol" (CLLB: 103).

Kutipan (4.14) di atas menjelaskan bahwa betapa sedihnya ketika seorang anak melihat Bapaknya yang terbaring tidak berdaya di rumah sakit. Terlihat 
bapaknya lebih tua sepuluh tahun dari usianya. Namun anaknya menyabarkan hatinya dan selalu berusaha dan berdoa agar bapaknya bisa sembuh kembali dan melanjutkan hidup seperti biasanya.

(4.15) "Ternyata kau menatapku karena cinta seorang kakak pada adiknya yang telah tiada. Sekuat tenaga kutahan dengan penuh sabar agar bulir-bulir kristal tak luruh, jatuh di depan kalian" (CLLB: 111).

Kutipan (4.15) di atas menjelaskan bahwa tidak semua harapan sesuai dengan kenyataan. Berharap wanita yang dicintai juga mencintainya namun, wanita tersebut malah mengatakan dia menganggap cintanya seperti kakak dan adik bukan cinta seperti pada kekasihnya. Dia menahan dengan sabar air mata untuk tidak jatuh ke pipi. Bersabar menerima cobaan adalah suatu keikhlasan yang harus menerima jika segala sesuatu yang diharapkan belum tentu sesuai dengan kenyataan yang ada.

\section{(4.16) "Lelaki yang saya sukai itu telah melukai} dengan keputusannya untuk menghilang, lalu meminta saya menunggu di sini, tapi tak datang menemui. Sungguh, saya akui diri ini begitu sabar karena mau dilukai cinta yang belum tentu jodoh" (CLLB: 145).

Kutipan (4.16) di atas menjelaskan bahwa betapa kecewanya seorang wanita ketika mengharapkan lakilaki yang dia cintai datang menemuinya dan itu yang di rasakan oleh gadis desa ini. Dia merasa sebagai seorang wanita yang sangat penyabar mau dilukai cinta yang belum tentu jodohnya.

(4.17) "Ayah meraih koran itu dan membacanya. Faisal tentu saya berharap setelah membacanya, Ayah akan berubah keputusan. Tapi Faisal harus menelan ludah getirnya ketika Ayah mencibir sambil meletakkan koran. Jadi itu yang menurutmu hebat? Jangankan denting kecapi bugis, bahkan gantungan kunci pun akan digilai orang-orang luar negeri” (CLLB: 147).

Kutipan (4.17) di atas menjelaskan bahwa betapa kecewa dan sedihnya Faisal harapan tidak sesuai kenyataan. Berharap orangtua perempuan mau menerimanya sebagai suami anaknya. Namun, yang dapat hanyalah hinaan dan cacian. Faisal tetap sabar dan memilih untuk pergi dari kehidupan wanita yang dia cintai. Bersabar menerima cobaan merupakn representasi sabar dalam wujud keihlasan.

(4.18) "Saya paham maksud ibu. Ia meminta saya sepertinya, menyerahkan semua keputusan pada Ayah. Suka atau tidak. Padahal dalam hati, saya ingin sekali berlari dari rumah, atau paling tidak melawan Ayah dengan suara tinggi, tapi hidup hanya memberi satu pilihan. Bersabarlah!"' (CLLB: 153).

Kutipan (4.18) di atas menjelaskan bahwa betapa sakitnya ketika semua apa yang kita inginkan dan kita harapkan dihalangi oleh kedua orang tua. Itulah dirasakan perempuan ini ingin sekali rasanya berlari dari rumah atau paling tidak melawan ayahnya. Namun, kenyataan itu menuntun perempuan itu untuk bersabar menerima kenyataan yang harus di hadapinya.

(4.19) "Ibu yang pertama memecah sunyi. Saya belum bisa bersikap apa pun, meski hanya sekedar mengangguk. Suara langkah Ayah yang meninggalkan ruang tamu, saya terjemahkan dengan kalimat memvonis:siapa pun dia, kamu harus menerimanya. Sidang ditutup. Tak ada banding!" (CLLB: 155).

Kutipan (4.19) di atas menjelaskan bahwa dia hanya bisa mengangguk dengan apa yang barusan dia dengar dari ayahnya. Dia hanya bisa sabar dan menuruti semua perkataan ayahnya demi kepatuhan seorang anak pada orang tuanya. Bersabar menerima cobaan adalah suatu jalan yang terbaik yang dapat dilakukan oleh seluruh umat manusia.

(4.20) "Selamat tinggal, Faisal! Batin saya sambil melangkah ke ruang tamu untuk menemui lelaki pengusaha pilihan Ayah. Saya tak bisa membiarkan diri dalam kebodohan panjang dengan mempertahankan cinta yang bukan jodoh, meski waktu telah membuat saya tangguh untuk terluka" (CLLB: 156-157).

Kutipan (4.20) di atas menjelaskan bahwa hati perempuan yang terluka karena tidak direstui dengan oarng yang dia cintai namun tetap bersabar wlau menangis dalam hati. Dia menyerahkan jalan hidupnya kepada Allah. Representasi kesabaran perempuan ini memperlihatkan dia sabar menerima cobaan, ikhlas, dan tabah.

(4.21) "Aku bakal kangen terus sama kamu, sama ibu! Nessa memecah hening. Bening air matanya leleh menderas. Matanya menatapku penuh. Mata yang penuh cinta" (CLLB: 162).

Kutipan (4.25) di atas menjelaskan bahwa Nessa harus pergi meninggalkan ibu dan laki-laki yang dianggap kakaknya itu untuk melanjutkan sekolah ke luar negeri. Nessa merasa bahwa mereka merupakan keluarga yang sangat berharga baginya. Air matanya 
jatuh dengan deras ke pipi. Namun Nessa tetap menyabarkan hatinya meninggalkan Ibu dan Kakak Yng dicintainya demi mencapai cita -cita.

(4.22) "Merawatnya dengan telaten, menunggui sampai dia sembuh dan mulai lagi menjalani kehidupan seperti semula. Namun yang terjadi sungguh di luar harapan. Berbulan-bulan Mas Dibku sayang tetap berbaring di tempat tidur. Kondisinya kian bertambah buruk" (CLLB: 175).

Kutipan (4.22) di atas menjelaskan bahwa betapa sedihnya melihat suaminya terbaring di tempat tidur tidak berdaya akibat kecelakan itu. Istrinya dengan telaten menunggui, merawatnya sampai dia sembuh dan mulai lagi menjalani kehidupan seperti semula. Namun yang diharapkan tidak sesuai kenyataan. Ternyata penyakit suaminya semakin parah. Kondisinya kian bertambah buruk. Namun kesabaran dalam merawat suaminya dapat mengatasi kondisi buruk yang dirasakannya. Bersabar menerima cobaan adalah suatu ujuan yang Allah berikan pada Umatnya. Untuk melihat seberapa sabar umatnya dalam menghadapi cobaan yang datang.

(4.23) "Dalam perjalanan ke kantor, banyak hal berputar dan menyesaki pikiranku. Tentang bulan madu yang hanya sesaat. Tentang sakitnya Mas Didku sayang, sikap Mama, serta sikap orang-orang yang seolah ingin mengambil keuntungan dari peristiwa yang $\mathrm{ku}$ alami” (CLLB: 179).

Kutipan (4.23) di atas menjelaskan bahwa betapa sedih dan terlukanya istri ketika melihat suaminya berbaring lemah tidak berdaya, ditambah lagi dengan sikap ibunya dan rekan-rekan kerjanya yang menyuruhnya utuk menikah lagi. Namun, istrinya tetap sabar dan percaya bahwa mas Didnya dapat sembuh kembali. Bersabar menerima cobaan adalah tingkat kedewasaan serta tingkat keimanan kita dalam menjalni semuanya. Semakin sabar kita menghadapi cobaan semakin tinggi mula derajat kita di mata Allah.

(4.24) "Bunda, hati aku seperti berlubang, sakit sekali. Bunda.... bangun, Bunda!. Hingga akhirnya, setelah merasakan kehampaan yang panjang...."Bunda, kalau Bunda kesakitan, Bunda pergi saya ya, Bunda? Yunnan nggak apa-apa kok, nggak ada Bunda. Tidak ada suara lagi dalam waktu lama, hanya rintihan halus" (CLLB: 195).

Kutipan (4.24) di atas menjelaskan bahwa betapa kuat dan hebatnya seorang anak yang mengatakan kepada ibunya untuk pergilah jika bunda meraskaan kesakitan. Yunna tidak apa-apa tidak ada bunda. Betapa kuat dan tegarnya anak melihat ibunya akan dipanggil Allah untuk selamanya. Sikap Yunna memperlihatkan representasi sikap sabarnya saat menyaksikan Ibunya dalam sakaratul maut. Bersabar menerima cobaan yang diberikan oleh Allah dan akan memberikan kekuatan bagi manusia.

(4.25) "Tolonglah $\mathrm{Bu}$, saya sudah tidak tahu lagi harus berbuat apa. Saya selalu berusaha memberikan yang terbaik, tapi ia seperti tidak bisa melupakan ayahnya. Bahkan saya sedang pusing memikirkan kakaknya Citra, Dita" bukan upaya membela diri." (CLLB: 202).

Kutipan (4.25) di atas menjelaskan bahwa betapa gigihnya seorang Ibu menghadapi anak yang selalu menyusahkannya. Namun kenyataan ini justru memberikan kesabaran kepadanya untuk selalu berupaya meminta pendapat kepada Ibunya untuk mengatasi masalah anak-anaknya. Bahkan dia dengan sabar tetap berusaha memberikan yang terbaik untuk anaknya.

(4.26) "Perempuan di hadapannya menunduk berangsur membuka mulut dan berbicara dengan suaranya bergetar, "Setiap hari. Hampir setiap hari ia selalu berteriak, Ayah....Ayah.....Ayah....!" (CLLB: 202).

Kutipan (4.26) di atas menjelaskan bahwa ibu yang menahan air matanya melihat anaknya yang selalu mengingat ayahnya yang sedang dalam penjara. Ibunya menahan air mata sekuatnya dan berbicara dengan suara yang bergetar mengingat semua yang telah terjadi. Kutipan di atas memperlihatkan representasi sikap sabar seorang istri dan seorang Ibu yang menghadapi anakanak yang selalu mengingat ayahnya di penjara.

\section{SIMPULAN}

Berdasarkan hasil penelitian dan pembahasan yang telah dijabarkan pada bab sebelumnya, maka dapat disimpulkan bahwa novel Cinta Laki-laki Biasa Karya Asma Nadia mengandung representasi sikap sabar. Representasi sikap sabar terlihat dari kutipan-kutipan berbentuk kata, kalimat bahkan paragraf yang terdapat dalam novel Cinta Laki-laki Biasa Karya Asma Nadia. Representasi sikap sabar dalam menerima berbagai cobaan dalam Novel Cinta Laki-laki Biasa Karya Asma Nadia terdapat 26 kutipan.

\section{Saran}

Berdasarkan kesimpulan yang telah dikemukakan di atas, maka dapat di sarankan : 
1. Penikmat sastra dapat menyeleksi novel-novel yang dijadikan bahan bacaan yang bermuatan nilai-nilai kemanusiaan.

2. Bagi sastrawan disarankan dapat memproduksi karya sastra yang mengandung unsur tuntunan kehidupan manusia.

3. Bagi guru di sekolah disarankan dapat memilih bahan ajar sastra dari novel-novel yang memuat unsur tuntutan kemanusiaan.

\section{DAFTAR PUSTAKA}

Semi, Atar. 2012. Metode Penelitian Sastra. Bandung: CV Angkasa.

Siswantoro, 2010. Metode Peneltian Sastra. Yogyakarta: Pustaka Pelajar.

(https://daerah.sindonews.com.topic.17/04/2018).

(http://www.Referensibukubagus.Wordpress.Com.17/04/ 2018). 